\title{
The Evaluation of Narcotic and Psychotropic Reporting Systems (SIPNAP)
}

\author{
Diah Kartika Putri ${ }^{1}$, Prasojo Pribadi ${ }^{1}$, Agus Setiawan ${ }^{2 *}$
}

\author{
${ }^{1}$ Department of Pharmacy, Universitas Muhammadiyah Magelang Magelang, Indonesia \\ ${ }^{2}$ Department of Informatics Engineering, Universitas Muhammadiyah Magelang Magelang, Indonesia \\ *Corresponding author. Email: setiawan@ummgl.ac.id
}

\begin{abstract}
SIPNAP is a system used to report the use of narcotics and psychotropic drugs in Indonesia. This study aims to determine the level of usability in the narcotics and psychotropic reporting system (SIPNAP). This research is a quantitative descriptive study with a purposive sampling approach and with Cross-Sectional sampling techniques - this research conducted in the City and Magelang Regency pharmacies with 113 respondents. The result of this research showed that the satisfaction of users of narcotics and psychotropic reporting information systems is in the moderate category or quite satisfied. The level of user satisfaction of SIPNAP has the highest percentage in the aspect of reliability. The usability level of SIPNAP is stated as good, with an average value of 2.8 from a scale of four.
\end{abstract}

Keywords: SIPNAP, pharmacy, usability, evaluation system, drugs

\section{INTRODUCTION}

Abuse of narcotics and psychotropic drugs in 2003-2006, narcotics cases in Indonesia rose by an average of $30.39 \%$ per year, except in 2008, it dropped to $12.27 \%$ [1]. Based on data from the World Drugs Reports 2018 published by UNODC, states that as many as 275 million people in the world or 5.6\% of the world's population (aged 15-64 years) have consumed drugs. While in Indonesia, BNN as the focal point in the field of Prevention and Eradication of Narcotics Abuse and Circulation (P4GN) pocketed the number of drug abuse in 2017 as many as $3,376,115$ people in the age range of 10-59 years [2].

Pharmacy is a pharmaceutical service facility, a place where pharmacy practices are carried out by a Pharmacist [3]. The government, through the Ministry of Health, has instructed pharmacies to report the use of narcotics and psychotropic drugs in the supervision of narcotics and psychotropic drugs, which is useful in minimizing drug abuse.

SIPNAP is a system used to report the use of narcotics and psychotropic drugs in all pharmaceutical service facilities that will simplify and speed up reporting from the City and District Health Offices to the Central Health Office. The function of SIPNAP is to improve the accuracy and compliance in reporting narcotics and psychotropic use. Supporting the development of good SIPNAP software will undoubtedly enhance the quality and quantity of reporting in cities and districts in facilitating the monitoring of progress or illegal leakage [4].

Based on research conducted by Batenburg et al. (2008), that the information technology strategy in the use of the system will largely depend on the experience of the Pharmacy Information System (PIS) possessed by the pharmacist [5], [6]. This insight and expertise can increase pharmacist satisfaction in using PIS. However, according to Setiani (2012), the problem that occurred in SIPNAP software was $33.33 \%$, which was the most common problem in many regions of Indonesia [7]. Many people consider that the software is less user-friendly, so the software needs to be improved to make it easier to operate. This problem confirmed by the results of the initial survey and interviews with several Pharmacists in Magelang, SIPNAP is challenging to operate. It takes a long time to run the SIPNAP system, and if something goes wrong, it must take care of it to the center in Jakarta. The provision of guidance to avoid operation errors and to facilitate the operation of SIPNAP software is very much needed.

Based on the description, the researcher wants to research the City and Regency of Magelang with the title "Evaluation of Narcotics and Psychotropic Reporting Systems (SIPNAP) from User Perception in City and Regency Pharmacy, Magelang."

\section{MATERIALS AND METHODS}

\subsection{Study design and data collection}

This research is a quantitative descriptive study with crosssectional research, which was conducted during NovemberDecember 2019 at the Magelang Pharmacy (113 respondents). The sampling technique used in this study was purposive sampling method with the criteria of a pharmacy officer who had operated SIPNAP twice or more. Therefore, he became a research respondent.

\subsection{Data Analysis}

The research instrument used was a questionnaire. The questionnaire to be distributed consisted of 20 question items. Each statement in this questionnaire will be assessed using a Likert scale, which is divided into four scales with 
a score of 1-4. This questionnaire contains five variables namely completeness (3 items), appearance and efficiency (5 items), easy to learn (4 items), errors (4 items), and satisfaction (3 items) adapted from [5][8]. The first process involves linguists to translate the questionnaire into Indonesian to avoid mistakes in translating. Next, two academic experts were involved in evaluating the words and clarity of the questionnaire. Before use, 60 respondents were tested to ensure the validity and reliability of the questionnaire. The questionnaire validity test using the Corrected item-total Correlation method with valid criteria when calculating $r>0,250$ [9] and the reliability test using the Cronbach Alpha method with reliable criteria if the
Cronbach Alpha value $>0.60$ [10]. The validity test results contained one invalid item question, so it was deleted from the questionnaire. The question items to be distributed for the actual sample consist of 19 question items.

The results of the study will be analyzed using descriptive methods and cross-tabulation with SPSS 21 software. The data obtained will be categorized into three categories, using the following formula [11]

$$
\begin{array}{ll}
\text { Low } & : X<(\mu-1,0 \sigma) \\
\text { Medium } & :(\mu-1,0 \sigma) \leq X<(\mu+1,0 \sigma) \\
\text { Height } & : X \geq(\mu+1,0 \sigma)
\end{array}
$$

Information:

$\mathrm{X}=$ Score of respondents' answers.

\begin{tabular}{|c|c|c|c|}
\hline Variable & Frequency & Percentage & p-value \\
\hline \multicolumn{4}{|l|}{ Age (In years) } \\
\hline $18-30$ & 57 & $50.44 \%$ & \multirow{3}{*}{0.71} \\
\hline $31-40$ & 48 & $42.48 \%$ & \\
\hline$>40$ & 8 & $7.08 \%$ & \\
\hline \multicolumn{4}{|l|}{ Gender } \\
\hline Female & 30 & $26.55 \%$ & \multirow{2}{*}{0.79} \\
\hline Male & 83 & $73.45 \%$ & \\
\hline \multicolumn{4}{|l|}{ Study Program } \\
\hline Senior high school & 16 & $14,15 \%$ & \multirow{6}{*}{0.00} \\
\hline S1- Accounting & 1 & $0.88 \%$ & \\
\hline S1-Law & 1 & $0.88 \%$ & \\
\hline S2- Farm & 4 & $3.54 \%$ & \\
\hline D3-Farm & 32 & $28.32 \%$ & \\
\hline Pharmacist & 59 & $52.21 \%$ & \\
\hline \multicolumn{4}{|l|}{ Position } \\
\hline AA & 34 & $30.09 \%$ & \multirow{6}{*}{0.15} \\
\hline Admin & 2 & $2.65 \%$ & \\
\hline APA & 54 & $47.79 \%$ & \\
\hline APING & 5 & $4.42 \%$ & \\
\hline PSA & 7 & $6.19 \%$ & \\
\hline TTK & 10 & $8.85 \%$ & \\
\hline \multicolumn{4}{|l|}{ Year of work } \\
\hline$<1$ & 11 & $9,73 \%$ & \multirow{3}{*}{0.11} \\
\hline $1-3$ & 39 & $34,51 \%$ & \\
\hline$>3$ & 63 & $55,75 \%$ & \\
\hline \multicolumn{4}{|c|}{ History SIPNAP Reporting in Pharmacy } \\
\hline Never & 9 & $9.73 \%$ & \multirow[t]{3}{*}{0.02} \\
\hline Sometimes & 30 & $34.51 \%$ & \\
\hline Always & 74 & $55.75 \%$ & \\
\hline \multicolumn{4}{|l|}{ SIPNAP training } \\
\hline Never been & 29 & $25.66 \%$ & \multirow{5}{*}{0.67} \\
\hline $1 \mathrm{x}$ & 45 & $39.82 \%$ & \\
\hline $2 \mathrm{x}$ & 16 & $14.16 \%$ & \\
\hline $3 x$ & 6 & $5.31 \%$ & \\
\hline$>3 \mathrm{x}$ & 17 & $15.04 \%$ & \\
\hline \multicolumn{4}{|l|}{ Ever use SIPNAP } \\
\hline $2 \mathrm{x}$ & 7 & $6.19 \%$ & \multirow{3}{*}{0.57} \\
\hline $3 x$ & 6 & $5.31 \%$ & \\
\hline$>3 x$ & 100 & $88.50 \%$ & \\
\hline
\end{tabular}

\section{RESULTS AND DISCUSSION}

Table 1 Demographic Data of Students

Based on Table 1, the data obtained can be stated from 113 statements of the majority of respondents consisting of women $(73.45 \%)$, have a pharmacist education history $(52.21 \%)$ and have APA status $(47.79 \%)$, have worked for $>$ 3 years $(55,75 \%)$, have attended SIPNAP training $(74.32 \%)$ and always do SIPNAP reporting (65.49\%). Based on the chi-square test results of educational history, position, and reporting a history of SIPNAP in pharmacies have a relationship with satisfaction using SIPNAP because the pvalues $<0.05$, the significance value is further from 0.05 declared no relationship [10] and this study is in line which shows a person's satisfaction can be influenced by the level 
of education [8]. Education will make a person increase knowledge about something, such as narcotics and psychotropic reporting information systems, and the higher a person's education will have an impact, the higher the satisfaction limit set. The higher the position in an agency, the higher the perception of satisfaction of use. The more often someone uses or reports on SIPNAP, it will affect the understanding and satisfaction of SIPNAP.

The EFA was used to determine the validity of the instrument (the component analysis group and the rotation method) from the questionnaire [12] the following are the results of the EFA test:

Table 2 Exploratory Factor Analysis (EFA)

\begin{tabular}{|c|c|c|c|c|}
\hline Variable & Item's & Mean \pm SD & Loading factor & Cronbach's Alpha \\
\hline \multirow[t]{5}{*}{ Efficiency } & SIPNAP is by the conditions at the pharmacy & $2.99 \pm 0.47$ & 0.601 & \multirow{5}{*}{0.79} \\
\hline & Operating the main menu requires too many actions & $2.74 \pm 0.62$ & 0.592 & \\
\hline & Error feedback from SIPNAP is clear & $2.77 \pm 0.50$ & 0.612 & \\
\hline & Overall, I am satisfied with SIPNAP & $2.89 \pm 0.43$ & 0.766 & \\
\hline & SIPNAP suits my needs & $2.91 \pm 0.47$ & 0.769 & \\
\hline \multirow[t]{3}{*}{ Learnability } & The operation of SIPNAP requires a long time & $2.81 \pm 0.53$ & 0.727 & \multirow{3}{*}{0.77} \\
\hline & $\begin{array}{l}\text { The operation of SIPNAP is complicated and can only be done } \\
\text { by certain pharmacies }\end{array}$ & $2.87 \pm 0.56$ & 0.758 & \\
\hline & $\begin{array}{l}\text { It takes a long time to operate the system after a long period of } \\
\text { disuse. }\end{array}$ & $2.68 \pm 0.60$ & 0.813 & \\
\hline \multirow{4}{*}{$\begin{array}{l}\text { Completeness } \\
\text { dan interface }\end{array}$} & SIPNAP has incomplete information & $2.79 \pm 0.51$ & 0.726 & \multirow{4}{*}{0.79} \\
\hline & The menu on SIPNAP is not well organized & $2.80 \pm 0.54$ & 0.654 & \\
\hline & The data presented by SIPNAP is clear and easy to understand & $2.97 \pm 0.49$ & 0.721 & \\
\hline & SIPNAP is fast in responding to user activity & $2.90 \pm 0.53$ & 0.777 & \\
\hline \multirow[t]{3}{*}{ Error } & Errors in SIPNAP are challenging to fix & $2.36 \pm 0.68$ & 0.686 & \multirow{3}{*}{0.68} \\
\hline & Errors often occur during SIPNAP use & $2.78 \pm 0.51$ & 0.725 & \\
\hline & SIPNAP is slow to return to normal after an error has occurred & $2.66 \pm 0.56$ & 0.666 & \\
\hline
\end{tabular}

Based on Table 2, results from 19 question items, there are four invalid items because the loading factor is less than 0.50 (Putri, 2017) and Cronbach alpha $<0.60$ [10]. Table 2 shows the results of the validity test after the invalid items were deleted. The results of the validity test showed that 15 items were declared valid and formed four factors that were able to explain satisfaction with usability of $64.696 \%$. The results of the factor analysis form the four dimensions of Usability as follows:

a. Factor one consists of SIPNAP completeness (A2), appearance and efficiency (B4), error (D3), satisfaction (E2, E3), explain $36,029 \%$ of the total variance, and is declared "efficiency."

b. The second factor consists of variables that are easy to learn $(\mathrm{C} 1, \mathrm{C} 2$, and $\mathrm{C} 3)$, explain from $11,450 \%$ of the total variance, and can be stated "learnability."

c. The third factor consists of the completeness variable (A3), and the appearance and efficiency (B1, B2, B3) explain $9,248 \%$ of the total variance and can be stated as "completeness and interface."

d. Factor four consists of error variables (D1, D2, D3) explaining $7.969 \%$ of the total variance and can be declared "error."

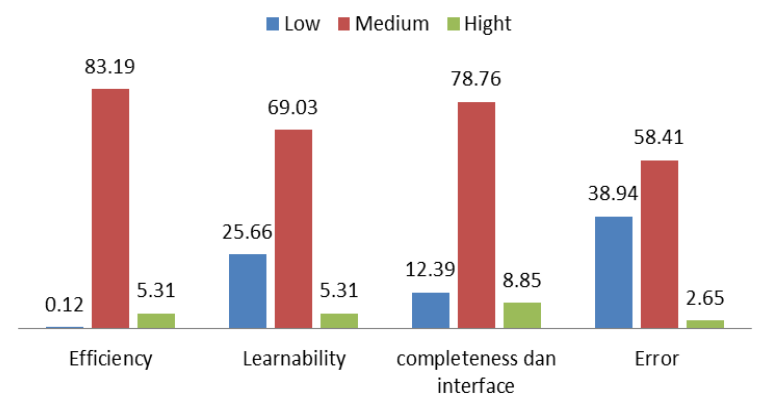

Figure 1 Percentage of Respondent's Satisfaction Statement

\subsection{Satisfaction with Narcotics Reporting Information System Efficiency}

The percentage of SIPNAP user satisfaction as much as $83.19 \%$ expressed quite satisfied with efficiency, this is in line with research conducted information systems can encourage increased efficiency and effectiveness of services in hospitals along with the smooth flow of information originating from activities hospital operations [13].

\subsection{Satisfaction with the Learnability of Narcotics and Psychotropic Reporting Information Systems}

The percentage of SIPNAP user satisfaction $69.03 \%$ stated that they were quite satisfied in terms of learning how to use SIPNAP. This was supported by the statements of respondents in Table 2. This study is in line with research conducted, which states that learnability is how fast a user has never been seeing, or the system can learn it to do necessary tasks. Therefore, it can affect the satisfaction of respondents. The higher the level of learnability, the higher the satisfaction of respondents [14].

\subsection{Satisfaction with Completeness and Interface of Narcotics and Psychotropic Reporting Information Systems}

Table 2 shows the percentage of SIPNAP user satisfaction as much as $78.76 \%$ stated that they were quite satisfied with 
[3] Permenkes RI, Standar Pelayanan Kefarmasian di Apotek. 2014, pp. 1-33. of respondents. This study is in line with the comments of respondents conducted that the level of satisfaction of respondents to the completeness of an information system of Immanuel Bandung Hospital as much as 91\% had a level of satisfaction with the category of moderate or quite satisfied [8].

\subsection{Satisfaction with Narcotics and Psychotropic Reporting System Errors}

The percentage of SIPNAP user satisfaction as much as $58.41 \%$ stated that they were quite satisfied with the error, this is supported by the statements of respondents, this research is by the theory that information systems implemented are rarely perfect, users will find errors (bugs). They will find design flaws and implementations that require attention and improvement [15].

\section{CONCLUSION}

Based on the research of narcotics and psychotropic reporting systems that have been carried out in all pharmacies in the City and Regency of Magelang, it shows that the satisfaction of users of information systems on narcotics and psychotropic reporting is included in the moderate or quite satisfied category. The percentage of SIPNAP user satisfaction was $83.19 \%$, which stated that they were quite satisfied with the efficiency indicators, which meant that the SIPNAP was not difficult in its operation. $69.03 \%$ indicated that they were quite confident with the learning ability indicators showing that SIPNAP was easy to learn. $78.76 \%$ stated that they were quite satisfied with the completeness and interface indicators, which meant that the menus were complete, and the interface was clear. Furthermore, the weakness of SIPNAP is only $58.41 \%$, which states that they are quite satisfied with the error indicators; this shows that SIPNAP still has many errors and difficulties in its recovery. The level of user satisfaction with SIPNAP, which has the highest percentage is in the aspect of reliability. The usability level of SIPNAP is stated as good, with an average value of 2.8 from a scale of four.

\section{REFERENCES}

[1] G. Dewi, Mirah Kusuma; Lestari, Diah Widya; Wirasulta, "Tingkat Penyalahgunaan Narkotika dan Psikotropika pada Pelajar SLTA (SMA/SMK) di Kota Denpasar,” Indones. J. Leg. Forensic Sci., vol. 4, pp. 14, 2014

[2] Puslidatin, "Penggunaan Narkotika di Kalangan Remaja Meningkat," 2019.

https://bnn.go.id/penggunaan-narkotika-kalanganremaja-meningkat/ (accessed Sep. 01, 2019).
[4] A. Rusli, "Awasi Penggunaan Narkotika, Dinkes Makassar Sosialisasi Aplikasi SIPNAP Berbasis Web," 2019. https:/www.makassarinfo.co/2019/03/22/awasipenggunaan-narkotika-dinkes-makassar-sosialisasiaplikasi-sipnap-berbasis-web/ (accessed Sep. 01, 2019).

[5] E. van den Batenburg, Ronald; Broek, "Pharmacy information systems: the experience and user satisfaction within a chain of Dutch pharmacies," J. Electron. Healthc., vol. 4, no. 2, pp. 119-131, 2008.

[6] A. Setiawan, E. U. Artha, E. R. Arumi, Sunarni, A. Primadewi, and S. Nugroho, "Task Analysis of Facebook users on Frequently used Menus," J. Phys. Conf. Ser., vol. 1179, p. 012019, Jul. 2019, doi: 10.1088/1742-6596/1179/1/012019.

[7] N. Setiani, "Laporan praktek Kerja Profesi Apoteker Di Direktorat Produksi Dan Distribusi Kefarmasia Dan Alat Kesehatan Kementerian Kesehatan Republik Indonesia Periode 16 Januari-27 Januari 2012." Universitas Indonesia, Depok, pp. 1-100, 2012.

[8] G. Tampa'i, Randy; Satibi; Pamudji, "Evaluasi Peranan Sistem Informasi Manajemen Farmasi Ditinjau Dari Persepsi Pengguna Di Rumah Sakit Imanuel Bandung," J. Manaj. dan Pelayanan Farm., vol. 2, no. 3, pp. 178-185, 2012.

[9] I. Prisgunanto, Aplikasi Teori dalam Sistem Komunikasi Indonesia, 01 ed. Jakarta: Prenadamedia Group, 2017.

[10] I. Ghozali, Aplikasi Analisis Multivariate dengan Program SPSS, Edisi !V. Semarang: Badan Penerbit UNDIP, 2006.

[11] S. Azwar, "Metode Penelitian,” Yogyakarta: Pustaka Pelajar, 2017, pp. 1-146.

[12] M. Arab, S. M. G. Tabatabaei, A. Rashidian, A. R. Forushani, and E. Zarei, "The Effect of Service Quality on Patient loyalty: a Study of Private Hospitals in Tehran, Iran,” Iran. J. Public Health, vol. 41, no. 9, pp. 71-77, 2012, [Online]. Available:

http://ijph.tums.ac.ir/index.php/ijph/article/view/2520.

[13] M. M. Sari, G. Y. Sanjaya, and A. Meliala, "Evaluasi Sistem Informasi Manajemen Rumah Sakit (SIMRS) dengan Kerangka HOT-FIT," in Seminar Nasional Sistem Informasi Indonesia (SESINDO), 2016, pp. 203-208, [Online]. Available: http://is.its.ac.id/pubs/oajis/index.php/home/detail/1665 /EVALUASI-SISTEM-INFORMASI-MANAJEMEN- 
RUMAH-SAKIT-SIMRS-DENGAN-KERANGKAHOT-FIT.

[14] S. Galih and U. Pasundan, "Pengukuran Usability Menggunakan Metode Cognitive Walktrough pada

Sistem Informasi Aka," Researchgate. Bandung, pp. 16, 2013.

[15] K. V Whithen, Jeffery L; Bentley, Lonnie D;

Dittman, Metode Desain dan Analisis Sistem, 6th ed.

Yogyakarta, 2004. 